\title{
Tempos ruins
}

\author{
MARIA TERESA HORTA
}

-

Eu não descuro

recuso

censores e carcereiros

inquisidores e profetas

Que vaticinam desgraças

abrem veias

cortam versos

Trancam celas

espalham sombras

fecham postigos, janelas

Mandam pôr muros e grades

trazem presságios ruins

torturas, dores e vilezas

alcateias e mastins

Eu não descuro

procuro

a esperança acalentada

sonhada na desmesura

Entre ruínas passadas

sevícias, medos

torpezas

A poesia

e a beleza

A liberdade exaltada.

Lisboa, 03 julho 2012 